\title{
PLACE AND IDENTITY: Reading From God's Spider at the Federation Of Humanities And Social Sciences Congress
}

\author{
(University of Ottawa, 31 May 2015) \\ "Every human being is a colony." \\ Picasso \\ Cyril Dabydeen
}

\begin{abstract}
Being a guest-writer at the Federation of Humanities and Social Sciences Congress was an honour. I thank the Canadian Association of Commonwealth Language and Literature Studies (CACLALS) and the Association for Canadian and Quebec Literatures (ACQL) for hosting me to read from my new volume, God's Spider (Peepal Tree Press, UK)-a shortlisted finalist for the Guyana Prize for Literature (Best Poetry Book category). Indeed, a reading is always a special occasion for me; it's also a time of liminality-in-betweenness, if you will-- placelessness, a void, quest, looking or yearning for an identity; and being nowhere, but searching. Wanting. As a preamble to my reading, I touched on W.H. Auden's view that a poet should "mythologize the ground on which he walks." Having now lived for over four decades in Canada, I am well equipped to do this: mythologizing Canada, sometimes with post-colonial verve and style, or angst. Post-colonial, presumably because all art is political (see Salman Rushdie's essays in his Outside the Whale).
\end{abstract}

Mythologizing is a prevalent concept, seen palpably in no other artist, I believe, than novelist Wilson Harris (Guyanese-born, living in the UK) who, in fact, is the God's Spider persona in much of what's reflected in my new poetry collection. Harris has said that the writer aims to "explore the bottomless pool of origins" by going back into pre-Columbian cultures in the search for relevance, or what's resonant: in his case, by writing about the Guyana hinterland (which Harris is so well acquainted with)--as he invokes "the bone-flute of memory" over time. And the hinterland is his essential trope. Iconic Canadian literary scholar Northrop Frye comes to mind, also, when considering mythopoeia, if such-he had visited Guyana circa 1980, and in my poem "Annals of Time" in this new collection about his Guyana experience I poetically express it as "facing up again to what's/our common ancestry as Jung/would have it...."

In the ongoing sense of mythopoeia I also read from the most significant poem in this new volume, a poem entitled "Wilson Harris: Landed Surveyor": about the artist spinning the web of mystery in the creative process (this poem was first requested of me by scholar Judith Misrahi-Barak-of Universite Paul-Valery Montpellier, France, for her edited volume Another Life). Here Canada and Guyana are spatially interlinked as the essence of numinous activity. Interestingly, the spider symbolizing the web of mystery is also seen in Native Indian and African (read, anansi) mythology; it is perhaps universal. Aligned to this, in my mind, is the view that "geography is destiny": manifested in my back into memory as "mother of the muses" as I

Cultural and Pedagogical Inquiry, 2016, 8(1), pp. 1-5

ISSN 1916-3460 (C) 2016 University of Alberta

http://ejournals.library.ualberta.ca/index.php/cpi/index 
envisioned Guyana and Wilson Harris with

his objective correlative at Mariella

...the Carib bone-flute's

in this Amazon's gothic House of Usher....

Notably, the publisher's blurb of God's Spider highlights that the poems "make enlightening connections between ancient Greece and Amerindian myth in Guyana, and present tropes of the buried voices of the past," as I pay homage to Wilson Harris, and that "Cyril Dabydeen signals that he too is a rejector of absolutes, in search of multiple possibilities." Multiple possibilities, indeed, as I've become increasingly more conscious of pre-Columbian motifs and lore in association with the totemic European figure of Christopher Columbus, who features in many Caribbean-born creative writers' work-not least my own. I also view this in the wider context of voyaging and discovery and metaphorically going back to classical Greece, and inevitably to what's tied to history and the exploitation of indigenous peoples, slavery, and indenture labour.

A signature poem I read at the Congress is from an earlier collection-the work entitled "For Columbus," in which I imaginatively wrestle with the Columbus motif integrated with keeping the past alive; and each poem I write and read aims to go beyond being "a moment's monument" as I have perceived it--but, also with what is numinously alive in the poem's persona lamenting:

The Spanish Empire sinking in the background--

This treasure being all I am left with,

Bible in hand, the sun whipping by,

A lopsided moon sinking lower into the bottomless sea....

(See addendum)

References to Cortez and Montezuma as images keep being resonant-which I address in a new poem about Pizarro meeting Aztec-emperor Atahualpa in an after-life without obvious magic-realism (poem appended here). Another poem I alluded to and no doubt read, "Streets," also written in the same period as "For Columbus" (included here) directly specifies Canada in context as my place of destiny with immigrant angst, as the persona asks: "Do you understand that memory cannot disappear?/Give me the maple leaf and I will show you the veins/as I cry out emblems from far-off places...", and leads to the image of "Districts of the North" addressed, where

together we haul stones, boulders; we will build across the terrain in British Columbia

Quebec Ontario the Prairies Newfoundland. 
In my short stories in collections such as North of the Equator (Beach Holme/Dundurn, 2001), Play a Song Somebody (Mosaic Press, 2003), and My Multi-Ethnic Friends (Guernica Editions, 2013)-and in my novel Drums of My Flesh (TSAR Publications, 2005)--I've returned to these motifs and themes in sometimes poetic prose (as critics have said), including with animal imagery, e.g., images of the jaguar evocative of the hinterland's chthonic forces that the imagination comes to grips with. Not unexpectedly, in God's Spider are also poems with telling titles such as "Owl Night," "Birding the Cage," and "Hawk," as well as "Bicentenary" (on the slave trade), "Tombstone (Tobago)," and "Sarojini Naidu: Letter to Daughter Leilamani"-all from my perspective reflecting the infinite possibilities of the imagination.

The latter poem ("Sarojini Naidu") with its oblique Indian-feminist stance is a link to my ancestral indenture-labour past tied to destiny as geography (stated before). In conjuring up memory, I've also longed for the transcendental and the sublime as being integral to the artist's ultimate quest. Thus, images associated with the mystical and/or religious yearning stem from the actual and phenomenological, seen in many of my poems, but notably in "Cosmic Vision" in Unanimous Night (Black Moss Press, 2009), where the influence of Indian lore and mythology embedded in my psyche and imagination comes to play, albeit my Caribbean and Canadian spatial awareness; and indeed, I will continue to write in a temporal/linear fashion in the quest for authenticity.

A brief background here is apropos: my grandfather and other past relatives had been brought to the Guyana sugar plantations in one of the last indenture ships across the kala pani (this trafficking ended in 1917), and thus I grew up in a diverse Guyana-Caribbean milieu serving as a key formative influence; and no doubt, this explains my awareness of subcontinental and other Eastern motifs linked to aspects of mysticism that sometimes inform my perspective tied to my evolving Canadian consciousness. In context, I often read poems that reflect these markers on the psyche: such as "Rajasthani/Maharani" and "On Meeting Her Excellency Rama Devi (Governor of Himachel Pradesh, India)"-- which transmute experiences of my actual visit to India.

Juxtaposed with these are poems in my Unanimous Night collection such as "Immigrant's Song," "Sitting Cross-Legged in Moonlight," and "Liberty Avenue"-the latter two touching on the $9 / 11$ tragedy in the USA. Significantly, in the latter poem the epigraph is taken from Derek Walcott: that writing a poem "is perfection's sweat like raindrops on a statue's brow"-which I've echoed at the Congress reading.

The creative act is what sustains me as a writer as I associate the religio-spiritual impulse with the concrete and particular seen in a key poem, "Cosmic Vision," where the persona acts out the yearning and quest:

...even if it's

only a lotus flower blossoming, or

my seeing the St Lawrence: a miracle again-

that I twist \& twirl, one foot pressed down,

Nataraja-like, on a dwarf (ignorance, see),

and drums beating; and fire: oh fire,

Cultural and Pedagogical Inquiry, 2016, 8(1), pp. 1-5

ISSN 1916-3460 (C) 2016 University of Alberta

http://ejournals.library.ualberta.ca/index.php/cpi/index 
as I seek escape from illusion, non-attachment really -- nirvana in the offing.

Overall, in my writing I try to come to terms with aspects of phenomenology: the process of the creative mind at work, often in subconscious ways (which I suggest to my creative writing students at the University of Ottawa as I urge them to explore their own deeper impulses and sensitivities as they attempt to explore the sense of the "bottomless pool of origins"--referenced to Wilson Harris). Neurologist, Oliver Sachs' ("the poet laureate of medicine"), insights also come to me about the mind's internal capacities as I keep searching for new ways of engaging with my creative spirit. Sachs" view that "the brain is the most intricate mechanism in the world" will continue to resonate.

Memory, indeed-or just looking forward and backward in he Jungian sense of being Janus-faced-also sustains or inspires me as I go beyond "imaginary homelands" (a la Rushdie) while grappling with reality about my place in Canada as an immigrant from the South (see North of the Equator previously mentioned). In an earlier poetry collection, Uncharted Heart (Borealis Press, 2008), I quote an epigraph derived from Michael Ondaatje to the poem "Who We Are": "We own the country we grow up in, or else we become aliens and invaders"; here in this collection's cycle of poems the intent--according to the publisher's blurb-is for "epiphanies in awakening to mythologies by delving into inner recesses of our beings."

I've intimated some of these epiphanies-or attempts at them, I believe--at the Congress; and that "every human being is a colony" which I quote at the heading of this essay; or, as Hanif Kureishi has said, "we are all migrants from somewhere"-also coming to mind in the imagination's absorptive capacity--which all writers and artists are aware of as we assimilate ideas and sensations, and, importantly, what I've reflected upon in my newest poem "Gimlet Eye"-- appended here).

In associations with scholars and artists, many of whom I met again at the Congress, I think I've shared with their intellectualism and sometimes activism that evolves in the experience of a literary reading. Scholars and activists such as Cecille DePass, Lloyd Stanford, Mariam Pirbhai, Miguel Neneve, John Clement Ball, Tanis MacDonald, and others who were in attendance gave me this sense of beingness, above all else. Indeed, CACLALS and ACQL have enabled my reading, and I acknowledge thanks to scholars such as Dorothy Lane, Sarah Jameison, and Jody Mason.

As poet and fiction writer --I have written more books of fiction than poetry--I will keep fusing or yoking images in trying to put the right words into their right places (as Coleridge has said) while grappling with rhythms tied to my own inflections--sometimes stemming from a Caribbean-Creole source in my attempt to fashion identity towards realizing the essential self. This is seen, more symbolically, I think, as I was moved to read the final poem in God's Spider-"The Peacock's Eye"-towards conveying the essence of the Wilson Harris archetypal influencewhere I state: "In the middle of the road/I found myself in a dark wood" (the Dante epigraph to this collection), as the hinterland and metropole voices coalesce when 
The dark notes

rose everywhere,

so sombre, they broke

into a fountain of light,

a rainbow sparkling

from invisible sources,

as the savannah grew lonely,

when the sea broke...

into a wave-

the sense of being

lost with the hope

of being found,

once again. 